\title{
Sepsis Patients in Critical Care Units with Obesity: Is Obesity Protective?
}

Charlene Kalani $^{1}$, Tejaswi Venigalla ${ }^{2}$, Janay Bailey ${ }^{3}$, George Udeani ${ }^{4}$, Salim Surani ${ }^{\text {5, } 2,6}$

1. Medicine, Corpus Christi Medical Center, Corpus Christi, USA 2. Internal Medicine, Corpus Christi Medical Center, Corpus Christi, USA 3. Internal Medicine, Hunterdon Medical Center, Flemington, USA 4. Internal Medicine, Texas A\&M University, Kingsville, USA 5. Internal Medicine, Texas A\&M Health Science Center, Bryan, USA 6. Internal Medicine, University of North Texas, Dallas, USA

Corresponding author: Salim Surani, srsurani@hotmail.com

\begin{abstract}
Obesity is becoming a global health issue and its prevalence is increasing. It is associated with an increased incidence of illness and sepsis. While obesity is associated with increased morbidity and mortality, obesity has been found to be associated with improvement in mortality outcomes in sepsis when compared to leaner patients, a phenomenon described as an obesity paradox. However, the effect of obesity on mortality in adults requiring treatment for sepsis is unclear. Studies evaluating this effect are inconsistent and there is an increased morbidity still associated with obesity. As well, there are many limitations to these studies confounding interpretation. Future prospective studies minimizing bias and confounding factors are suggested to address this important clinical issue.
\end{abstract}

Received 02/03/2020

Review began 02/06/2020 Review ended 02/06/2020 Published 02/10/2020

\section{(c) Copyright 2020}

Kalani et al. This is an open access article

Categories: Family/General Practice, Internal Medicine, Pulmonology

Keywords: obesity, metabolically-healthy obese, metabolically-unhealthy obese, overweight, morbidly obese, sepsis, morbidity, mortality

\section{Introduction And Background}

Obesity is a rapidly growing challenge in the United States and around the globe. Around $70 \%$ of adults in the United States are overweight and $35 \%$ are obese [1,2]. Due to the high prevalence of obesity, there are an increasing number of obese patients being hospitalized in intensive care units (ICUs). Of the adults admitted to the ICUs, around $25 \%$ are overweight, obese, or morbidly obese [3]. Sepsis is the most common cause for admission to the ICU. Sepsis is associated with significant morbidity, mortality, and cost to the healthcare system. In the United States, septicemia was overall the 11th leading cause of death in 2010 according to the Centers for Disease Control and Prevention, and is the most common cause of death in the ICU $[4,5]$. Globally, there is in-hospital mortality of $15 \%$ with sepsis and $25 \%$ for severe sepsis [6]. Mortality increases to $40 \%-50 \%$ in patients with complications and in lower-income countries [7,8]. An estimated $50 \%$ of patients with sepsis require ICU admission and $17 \%$ require intubation [5]. The estimated total cost in the United States for severe sepsis is $\$ 24.3$ billion dollars per year [9].

Obesity is known to reduce overall life expectancy and is associated with an increased incidence of chronic health conditions such as type two diabetes mellitus, hypertension, heart failure, and coronary artery disease. The World Health Organization defines obesity as a body mass index (BMI) $>30 \mathrm{~kg} / \mathrm{m} 2$ (Table 1) [10].

\begin{tabular}{|c|c|}
\hline Classification & BMI (kg/m2) \\
\hline Underweight & $<18.5$ \\
\hline Normal weight & $18.5-24.9$ \\
\hline Overweight & $25-29.9$ \\
\hline Obese class I & $30-34.9$ \\
\hline Obese class II & $35-39.9$ \\
\hline Obese class III/ Morbid obesity & $\geq 40$ \\
\hline
\end{tabular}

TABLE 1: The World Health Organization Body Mass Indices Classification 
revealed in several studies to have better mortality outcomes compared to leaner patients. This unexpected finding has led to the "obesity paradox" where obese patients have lower-than-expected mortality outcomes compared to similar patients who have lower BMIs. This finding can also be found in several different disease states including chronic kidney failure requiring hemodialysis, skin/soft tissue infections, and heart failure [12-15]. The effect of obesity on outcomes with sepsis is still unclear. There have been several studies evaluating the association of obesity and outcomes with sepsis but results are conflicting [3]. We will try to address this issue in this review.

\section{Review}

In a prospective, observational cohort study by Prescott et al., 1,404 severe sepsis hospitalizations were analyzed for in-hospital, 90-day, and one-year mortality in normal weight, overweight, obese, or severely obese patients [16]. The study found that higher BMI was associated with statistically significant improved one-year mortality with obese (odds ratio (OR) 0.59 ; $95 \%$ confidence interval (CI) $0.39-0.88$ ) and severely obese patients (OR 0.46; 95\% CI 0.26-0.80) had the lowest mortality rate [16]. While the length of stay in a healthcare facility was greater for obese patients, the study found that average daily utilization was similar with normal and overweight survivors [16]. Obese sepsis survivors utilized more Medicare spending than lower BMIs but the study attributed this to longer survival of the patients [16].

Several retrospective chart review studies evaluated the impact of obesity on survival [17-21]. In a retrospective study by Wochenscher et al., 301 underweight, normal weight, overweight, and obese patients with septic shock were evaluated for outcomes [21]. Patient with BMI $>50 \mathrm{~kg} / \mathrm{m} 2$ were excluded [21]. The study found that overweight and obese patients were independently associated with a decreased risk of ICU death than normal weight patients in a multivariable model but this finding was not statistically significant (OR 0.93; 95\% CI 0.86-1.02, p=0.09) [21]. In a second study of 792 septic patients, the study found that survivors had a higher average BMI compared to non-survivors (27.6 vs. $26.3 \mathrm{~kg} / \mathrm{m} 2$, p=0.03) [19]. However, after adjusting for co-morbidities including age, severity of illness, length of stay, the association was no longer statistically significant (OR 0.52, $\mathrm{p}=0.03$ ). Similar findings were found in a retrospective, large, multicenter nested cohort study of 8,670 patients with septic shock [17]. The study found obese and very obese patients were associated with lower mortality. However, once again, the results became non-significant once adjusting for co-morbidities and sepsis interventions [17]. A retrospective cohort study of 1,779 patients with sepsis found no significant mortality worsening with obesity (OR 1.11; 95\% CI 0.85-1.41, p=0.47) but there was no difference in the hospital length of stay [18]. However, severely obese patients were found to have higher mortality than normal weight patients [18].

In a large meta-analysis including six studies that evaluated the effect of BMI on mortality in sepsis, severe sepsis, or septic shock in patients admitted to ICU, the study found overweight and obese BMIs were associated with significantly decreased mortality after adjusting for baseline variables (OR 0.83; $95 \% \mathrm{CI}$ 0.75-0.91, $\mathrm{p}=0.0002$ and OR 0.82; 95\% CI 0.67-0.99, $\mathrm{p}=0.04$, respectively) [4]. Morbid obese patients were not associated with decreased mortality, but these patients also did not have increased mortality [22]. Table 2 summarizes the details of select studies and their outcome.

\begin{tabular}{|c|c|c|c|c|c|c|}
\hline Study & $\begin{array}{l}\text { No. of } \\
\text { patients } \\
\text { Study Design }\end{array}$ & $\begin{array}{l}\text { Definitions/ } \\
\text { Comparator }\end{array}$ & $\begin{array}{l}\text { Mortality Benefit } \\
\text { Yes/No/NS and OR }\end{array}$ & $\begin{array}{l}\text { Mean } \\
\text { Length of } \\
\text { Stay in } \\
\text { Hospital } \\
\text { Increased } \\
\text { (days) }\end{array}$ & $\begin{array}{l}\text { Length of } \\
\text { Intubation }\end{array}$ & Comments/Notes \\
\hline $\begin{array}{l}\text { Arabi et } \\
\mathrm{al}^{17}(2013)\end{array}$ & $\begin{array}{l}8670 \text { patients } \\
\text { with septic } \\
\text { shock } \\
\text { Retrospective, } \\
\text { nested cohort }\end{array}$ & $\begin{array}{l}\text { Comparator: } \\
\text { Normal weight } \\
\text { Normal weight: } \\
\text { 18.5-24.99 } \\
\text { kg/m2 Obese: } \\
\text { BMI } 30-39.99 \\
\text { kg/m2 Very } \\
\text { Obese: } \text { BMI >40 } \\
\text { kg/m2 }\end{array}$ & $\begin{array}{l}\text { Crude: YES Obese- OR } \\
0.80,95 \% \mathrm{Cl} 0.66 \text { to } \\
0.97 ; p=0.02 \text { Very } \\
\text { obese- OR } 0.61,95 \% \\
\text { CI } 0.44 \text { to } 0.85 ; p=0.003 \\
\text { Adjusting for baseline } \\
\text { characteristics and } \\
\text { sepsis interventions: } \\
\text { NS Obese- OR } 0.80 \text {, } \\
95 \% \text { Cl } 0.62 \text { to } 1.02 ; \\
p=0.07 \text { Very obese- OR } \\
0.69,95 \% \text { Cl } 0.45 \text { to } \\
1.04 ; p=0.08\end{array}$ & $\begin{array}{l}\text { ICU LOS: } \\
\text { NS; } p=0.30 \\
\text { Obese- } 14.7 \\
\text { vs. } 12.5 \\
\text { Very obese- } \\
14.3 \text { vs. } \\
12.5 \\
\text { Hospital } \\
\text { LOS: YES; } \\
\text { p=0.02 } \\
\text { Obese- } 27.8 \\
\text { vs. } 31.8 \\
\text { Very obese- } \\
34.8 \text { vs. } \\
31.8\end{array}$ & N/A & $\begin{array}{l}\text { There were different approaches to } \\
\text { sepsis for obese and normal weight } \\
\text { patients }\end{array}$ \\
\hline & $\begin{array}{l}1,779 \text { patients } \\
\text { with }\end{array}$ & $\begin{array}{l}\text { Comparator: } \\
\text { Non-obese }\end{array}$ & & Hospital & & \\
\hline
\end{tabular}




\section{Cureus}

\begin{tabular}{|c|c|c|c|c|c|c|}
\hline $\begin{array}{l}\text { Gaulton et } \\
\text { al }{ }^{18}(2014)\end{array}$ & $\begin{array}{l}\text { presumed } \\
\text { sepsis } \\
\text { Retrospective } \\
\text { cohort }\end{array}$ & $\begin{array}{l}\text { Non-obese: } \\
\text { BMl >18.5 and } \\
<30 \mathrm{~kg} / \mathrm{m} 2 \\
\text { Obese: } \mathrm{BMl}>30 \\
\mathrm{~kg} / \mathrm{m} 2\end{array}$ & $\begin{array}{l}\text { NS OR 1.11, } 95 \% \text { Cl } \\
0.85-1.41, p=0.47\end{array}$ & $\begin{array}{l}\text { LOS: NS } 3.1 \\
\text { vs. } 3.83 \\
p=0.45\end{array}$ & N/A & $\begin{array}{l}\text { ICU location at time of presumed sepsis: } \\
\text { Obese } 74.2 \% \text { vs. } 69.4 \% \text { non-obese } \\
p=0.04\end{array}$ \\
\hline $\begin{array}{l}\text { Kuperman } \\
\text { et } \\
\text { al }^{19}(2013)\end{array}$ & $\begin{array}{l}792 \text { patients } \\
\text { with sepsis } \\
\text { Retrospective } \\
\text { chart review }\end{array}$ & $\begin{array}{l}\text { Comparator: } \\
\text { Normal weight } \\
\text { Underweight: } \\
\text { BMI <18.5 } \\
\text { Normal: BMI } \\
\text { 18.5-24.9 kg/m2 } \\
\text { Overweight: } \\
\text { BMI } 25.0-29.9 \\
\mathrm{~kg} / \mathrm{m} 2 \text { Obese: } \\
\text { BMI } 30.0-39.9 \\
\mathrm{~kg} / \mathrm{m} 2 \\
\text { Morbidly obese: } \\
\text { BMI 40.0-49.9 } \\
\mathrm{kg} / \mathrm{m} 2\end{array}$ & $\begin{array}{l}\text { Underweight: NS OR } \\
1.5,95 \% \mathrm{Cl} 0.67-6.3 \\
\text { Obese: NS OR } 0.72 \\
95 \% \mathrm{Cl} \text { and } \mathrm{p} \text { value not } \\
\text { reported Morbid } \\
\text { obesity: NS OR } 0.7 \text {, } \\
95 \% \mathrm{Cl} 0.12-4.2 ; \mathrm{p}= \\
0.19\end{array}$ & $\begin{array}{l}\text { NS; } p=0.64 \\
\text { Obese: } \\
9.0 \pm 8.1 \text { vs. } \\
9.3 \pm 8.5 \\
\text { Overweight: } \\
8.8 \pm 7.8 \text { vs. } \\
9.3 \pm 8.5 \\
\text { Morbidly } \\
\text { Obese: } \\
10.2 \pm 9.6 \\
\text { vs. } 9.3 \pm 8.5\end{array}$ & N/A & $\begin{array}{l}\text { BMI of } 27.6 \text { for survivors vs. } 26.3 \mathrm{~kg} / \mathrm{m} 2 \\
\text { among non-survivors ( } p=0.03 \text { ) }\end{array}$ \\
\hline $\begin{array}{l}\text { Pepper et } \\
\mathrm{al}^{23} \text { (2019) }\end{array}$ & $\begin{array}{l}55,038 \text { adults } \\
\text { with sepsis }\end{array}$ & $\begin{array}{l}\text { Comparator: } \\
\text { Normal Weight } \\
\text { Normal weight: } \\
\text { BMl } 18.5-24.9 \\
\mathrm{~kg} / \mathrm{m} 2 \\
\text { Overweight: } \\
25.0-29.9 \mathrm{~kg} / \mathrm{m} 2 \\
\text { Obese class } 1: \\
30.0-34.9 \mathrm{~kg} / \mathrm{m} 2 \\
\text { Obese class II: } \\
35.0-39.9 \mathrm{~kg} / \mathrm{m} 2 \\
\text { Obese class } \\
\text { III: }>40 \mathrm{~kg} / \mathrm{m} 2\end{array}$ & $\begin{array}{l}\text { YES Adjusted odds } \\
\text { ratio (95\% Cl) } \\
\text { Underweight: } 1.62 \\
(1.50-1.74) \\
\text { Overweight: } 0.73(0.70- \\
077) \text { Obese class I: } \\
0.61 \text { (0.57-0.66) Obese } \\
\text { class II: } 0.61 \text { (0.55-0.67) } \\
\text { Obese class III: } 0.65 \\
(0.59-0.71)\end{array}$ & $\begin{array}{l}\text { Similar } \\
\text { between } \\
\text { groups } \\
\text { ICU length } \\
\text { of stay: } 9 \\
\text { days; } \\
\text { interquartile } \\
\text { range, 6-15 } \\
\text { days } \\
\text { Hospital } \\
\text { length of } \\
\text { stay: } 8 \\
\text { days; } \\
\text { interquartile } \\
\text { range, 6-13 } \\
\text { days }\end{array}$ & N/A & $\begin{array}{l}\text { Sepsis defined with Sepsis-3 criteria } \\
\text { BMI calculated from data on or } \\
\text { preceding day of sepsis diagnosis (did } \\
\text { not include the weight change after fluid } \\
\text { administration) Included death or } \\
\text { hospice in mortality outcome } \\
\text { Confounders included demographic } \\
\text { factors, admission year, hospital-level } \\
\text { factors, infection factors, and severity of } \\
\text { illness }\end{array}$ \\
\hline $\begin{array}{l}\text { Prescott et } \\
\text { al }{ }^{17} \text { (2014) }\end{array}$ & $\begin{array}{l}1404 \text { patients } \\
\text { with severe } \\
\text { sepsis } \\
\text { Prospective, } \\
\text { cohort } \\
\text { Medicare } \\
\text { study } \\
\text { Followed } \\
\text { patients for } 1 \\
\text { year }\end{array}$ & $\begin{array}{l}\text { Comparator: } \\
\text { Normal Weight } \\
\text { Normal weight: } \\
\text { BMl } 18.5-24.9 \\
\mathrm{~kg} / \mathrm{m} 2 \\
\text { Overweight: } \\
\text { BMl } 25-29.9 \\
\mathrm{~kg} / \mathrm{m} 2 \text { Obese: } \\
\mathrm{BMI} 30.0-34.9 \\
\mathrm{~kg} / \mathrm{m} 2 \\
\text { Severely Obese: } \\
\text { BMI >35 kg/m2 }\end{array}$ & $\begin{array}{l}\text { YES Obese: OR 0.59; } \\
95 \% \mathrm{Cl}, 0.39-0.88 \\
\text { Severely Obese: OR } \\
0.46 ; 95 \% \mathrm{Cl}, 0.26-0.80\end{array}$ & $\begin{array}{l}\text { Hospital } \\
\text { LOS: NS } \\
\text { Obese: } 11.5 \\
\text { vs. } 12.5 \\
\text { Severely } \\
\text { Obese: } 12.5 \\
\text { vs. } 11.5\end{array}$ & N/A & $\begin{array}{l}\text { Total days in a healthcare facility and } \\
\text { Medicare expenditures greater for obese } \\
\text { ( } p<0.01 \text { for both comparisons) Average } \\
\text { daily utilization NS ( } p=0.44 \text { ) for } \\
\text { overweight and obese survivors } \\
\text { Medicare spending NS ( } p=0.65 \text { ) for } \\
\text { overweight and obese survivors Total } \\
\text { function limitations following severe } \\
\text { sepsis NS ( } p=0.64 \text { ) Increased } \\
\text { healthcare use concluded to be due to } \\
\text { longer survival }\end{array}$ \\
\hline \multirow[t]{2}{*}{$\begin{array}{l}\text { Wacharasint } \\
\text { et al } 20 \\
\text { (2013) }\end{array}$} & $\begin{array}{l}778 \text { patients } \\
\text { with septic } \\
\text { shock } \\
\text { Retrospective } \\
\text { cohort } \\
\text { analysis }\end{array}$ & $\begin{array}{l}\text { Comparator: } \\
\text { Normal weight } \\
\text { Normal weight: } \\
\text { BMI <25 kg/m2 } \\
\text { Overweight: } \\
\text { BMl } 25-29.9 \\
\mathrm{~kg} / \mathrm{m} 2 \text { Obese: } \\
\text { BMI }>30.0\end{array}$ & $\begin{array}{l}\text { 28-day mortality: YES } \\
\text { Overweight: } \mathrm{BMI}<25 \\
\mathrm{~kg} / \mathrm{m} 2 \text { vs. overweight, } \\
\mathrm{p}=0.10 \text { Obese: } \mathrm{BMI} \\
<25 \mathrm{~kg} / \mathrm{m} 2 \text { vs. obese, } \\
\mathrm{p}=0.01 \text { Overweight } \\
\text { versus Obese, } \mathrm{p}=0.2\end{array}$ & N/A & $\begin{array}{l}\text { No } \\
\text { difference } \\
\text { in days } \\
\text { alive and } \\
\text { free of } \\
\text { mechanical } \\
\text { ventilation } \\
\text { (obese } 11 \text {, } \\
\text { overweight } \\
10, \text { BMl } \\
<25 \mathrm{~kg} / \mathrm{m} 2 \\
6 \text { days; } \\
\mathrm{p}=0.36\end{array}$ & $\begin{array}{l}\text { Amount of fluid per body weight } \\
\text { significantly lower in overweight and } \\
\text { obese patients Day } 1 \text { through Day } 4 \text {; } \\
p<0.0001 \text { Days alive and free of renal } \\
\text { replacement therapy (obese } 25 \text {, } \\
\text { overweight } 24, \text { BMI }<25 \mathrm{~kg} / \mathrm{m} 224 \text { days; } \\
\mathrm{p}=0.93 \text { ) Norepinephrine: Obese } 0.14 \text {, } \\
\text { IQR } 0.09-0.25 \text { Overweight } 0.21, \text { IQR } \\
0.12-0.34 \mathrm{BMI}<25 \mathrm{~kg} / \mathrm{m} 20.26, \text { IQR } 0.15- \\
0.44 \mu \mathrm{g} / \mathrm{kg} / \mathrm{minute} \text { - } p<0.0001 \text { IL- } 6 \\
\text { significantly lower in obese and } \\
\text { overweight compared to }<25 \mathrm{~kg} / \mathrm{m} 2 \text { in } \\
\text { early phase of septic shock; } p=0.046\end{array}$ \\
\hline & & $\begin{array}{l}\text { Comparator: } \\
\text { Normal weight } \\
\text { Normal weight: }\end{array}$ & & & & MI for survivors vs. nonsurvivors: 27 \\
\hline
\end{tabular}




\section{Cureus}

\begin{tabular}{|c|c|c|c|c|c|c|}
\hline $\begin{array}{l}\text { Wurzinger } \\
\text { et } \\
\mathrm{al}^{21}(2010)\end{array}$ & $\begin{array}{l}301 \text { patients } \\
\text { with septic } \\
\text { shock } \\
\text { Retrospective } \\
\text { analysis on } \\
\text { prospectively } \\
\text { collected } \\
\text { database }\end{array}$ & $\begin{array}{l}\text { BMI 18.5-24.9 } \\
\mathrm{kg} / \mathrm{m} 2 \\
\text { Overweight: } \\
\text { BMI 25-29.9 } \\
\mathrm{kg} / \mathrm{m} 2 \text { Obese: } \\
\text { BMI 30.0-39.9 } \\
\mathrm{kg} / \mathrm{m} 2 \\
\text { Morbidly } \\
\text { Obese: } \mathrm{BMI}>40 \\
\mathrm{~kg} / \mathrm{m} 2\end{array}$ & $\begin{array}{l}\text { YES Overweight: OR } \\
0.43 ; 95 \% \text { CI 0.19-0.98; } \\
p=0.04 \text { Obese: OR } \\
0.28 ; 95 \% \text { Cl 0.08-0.93; } \\
p=0.04\end{array}$ & $\begin{array}{l}\text { ICU LOS: } \\
\text { NS; } \\
\text { Regression } \\
\text { coefficient } \\
0.03,95 \% \\
\mathrm{Cl}-0.15 \text { to } \\
0.21 ; \\
\mathrm{p}=0.74\end{array}$ & $\begin{array}{l}\text { NS } \\
\text { Regression } \\
\text { coefficient } \\
0.05 \text { days, } \\
95 \% \mathrm{Cl} \text { - } \\
0.1 \text { to } 0.2 \text {; } \\
p=0.49\end{array}$ & $\begin{array}{l}\text { vs. } 24 ; p=0.001 \text { Elevated BMI } \\
\text { independently associated with lower } \\
\text { frequency of acute delirium ( } p=0.04 \text { ) and } \\
\text { lower need for ICU re-admission } \\
(p=0.001 \text { ) Elevated BMI associated with } \\
\text { higher rate of ICU-acquired urinary tract } \\
\text { infections ( } p=0.02 \text { ) Need for mechanical } \\
\text { ventilation OR } 1.02,95 \% \text { Cl } 0.95-1.09 ; \\
p=0.66\end{array}$ \\
\hline
\end{tabular}

TABLE 2: Summary of Select Studies Evaluating Obesity Effect on Mortality in Sepsis

$\mathrm{BMI}=$ body mass index; $\mathrm{Cl}=$ confidence interval; LOS = length of stay; N/A = not applicable/not reported; NS = not significant; OR = odds ratio.

In a recent retrospective analysis by Pepper et al., 55,038 Sepsis-3 criteria septic adult patients were found to have lower short-term mortality in patients with higher body weight, including overweight and obese classes I, II, and III patients, compared to those with normal weight in both unadjusted and adjusted analyses for patient, infection, and hospital-level factors [23]. Hospital and ICU lengths of stays were also similar between the BMI categories. These results further indicate there may be an obesity paradox in sepsis [23]. Despite the possible mortality benefit seen with obesity, there are conflicting results on the potential for increased morbidity associated with obesity, including length of stay in ICU and length of intubation $[24,25]$.

\section{Pathophysiology}

The mechanism of the protective function with overweight and obese patients is not understood. One possible reason is that the elevated adipose tissue and associated energy stores may maintain the catabolic state induced by sepsis [26]. However, it is controversial if sepsis truly is a catabolic condition [27].

Another theory is that the systemic inflammatory response with sepsis may be different in obese patients than normal weight patients [28]. Ectopic fat in non-adipose tissue, such as visceral fat, leads to the unhealthy abnormalities that are associated with metabolic syndrome.

Metabolic syndrome is defined when at least three of the following are present [29]:

o Waist circumference $>102 \mathrm{~cm}$ in males $>88 \mathrm{~cm}$ in females

o Serum triglycerides $>150$ or receiving drug treatment for elevated triglycerides

o Serum high-density lipoprotein (HDL) $<40 \mathrm{mg} / \mathrm{dl}$ in men and $<50 \mathrm{mg} / \mathrm{dl}$ in women or receiving drug treatment for low HDL levels

o Blood pressure is $>130 / 85 \mathrm{mmHg}$ or receiving drug treatment for hypertension

o Fasting blood glucose is $>100 \mathrm{mg} / \mathrm{dl}$ or receiving drug treatment for elevated blood glucose

Visceral fat is associated with increased production of cytokines, elevated free fatty acid flux, insulin resistance, and gluconeogenesis [30]. Approximately $50 \%$ of overweight adults and $32 \%$ of obese individuals may be considered metabolically healthy due to the absence of the metabolic syndrome [31]. As well, about $24 \%$ metabolically-obese but normal weight individuals are estimated to be metabolically abnormal where they have a normal BMI but have metabolic syndrome [32]. This syndrome is associated with high risk of developing cardiovascular diseases and increased morbidity and mortality compared to those without the syndrome and may be associated with the chronic disease states of obesity.

A third possible observation for the obesity paradox is that adipocytes could be immunomodulating as obese patients have lower than expected proinflammatory cytokines during severe infection and acute lung injury $[20,33]$. This is possibly due to chronic inflammation due to obesity. The elevated concentrations of tumor necrosis factor (TNF)-receptors produced by visceral fat, may lead to a decrease in the harmful effects of excessive TNF production during sepsis [34]. Increased lipoprotein levels and adipose tissue may also bind and inactivate harmful bacterial products such as lipopolysaccharide, which augment the septic pathophysiology $[3,33]$. As well, levels of pro-inflammatory cytokine interleukin-6 is muted in obese patients [20]. Leptin, a cytokine that is produced and stored in adipocytes, is believed to have a protective role in the acute systemic inflammation seen with sepsis by regulating cell-mediated immunity, endothelial activation, and cytokine release. In critically ill patients with sepsis, there is an associated three-fold increased 
concentration of leptin [22]. Due to the large amount of adipocytes in obese patients, they naturally have increased production and storage of leptin and interleukin-10, another anti-inflammatory cytokine [35]. Elevated levels of leptin have been shown in some studies to have a benefit in mortality but this result is not uniform among all studies [36]. While these responses are thought to be due to the chronic inflammation of obesity, other chronic inflammatory conditions do not have the same mortality benefit seen with obesity in sepsis [37].

Additionally, adipose tissue is associated with increased renin-angiotensin-aldosterone system (RAAS) function. While the excessive RAAS function leads to hypertension associated with obesity, this may be protective during sepsis due to the decreased need for vasopressors, which are associated with many adverse effects $[17,20]$.

\section{Limitations}

However, there are many limitations identified in the current studies that demonstrate this relationship. There likely were many differences in sepsis interventions in the obese compared to lower BMIs, such as admission status and location and the administration of fluids, vasopressors, and antimicrobial therapy $[17,20]$.

In addition, concerns with obesity hypoventilation syndrome and acute-on-chronic hypercapnic respiratory failure may have led to selection bias of the medical staff caring for overweight or obese patients and more aggressive treatment. Current Surviving Sepsis Campaign (SSC) guidelines recommend noninvasive ventilator strategies first-line in patients with obesity-hypoventilation syndrome, but these methods are often contraindicated due to the underlying acidosis and altered level of consciousness associated with obesity hypoventilation syndrome [38]. The difficulties with intubation and mechanical ventilation due to body habitus of these patients including limited neck mobility, decreased mouth opening, and difficulties with patient positioning may also predispose providers to lower the threshold for ICU admission due to an anticipated difficult airway [3].

There also may be a bias in overestimating the severity of illness in obese patients. Illness severity scores do not usually account for obesity and have not been validated in obese patients [17]. For example, many components of the Acute Physiology and Chronic Health Evaluation (APACHE) II scoring may be affected by obesity and not the acute illness, such as oxygenation. This may have led to an increased level of care for patients in comparison to similar patients with lower BMI. In a study by Gaulton et al., obese patients were more likely to be in the ICU at the time of presumed sepsis in comparison to non-obese patients [18].

Current SSC guidelines recommend fluid resuscitation with an initial fluid bolus of at least $30 \mathrm{ml} / \mathrm{kg}$ for patients with severe sepsis and septic shock [38]. However, several studies have shown that overresuscitation with fluids may be harmful in septic patients and may exacerbate underlying respiratory dysfunction [39-41]. The SSC guidelines do not specify the weight to be used for fluid bolus calculations [38]. However, the studies the SSC guidelines base their recommendations on utilized body weight or a total volume of 2L. Several studies have shown that obese patients receive similar fluid volumes in sepsis to normal BMI with no worsening of outcomes [16,19]. This possibly provides a bias towards survival and better outcomes in obese patients.

In addition, studies have shown a decreased amount of vasopressors used per weight. There is no guidance on whether vasopressors should be dosed based on weight $(\mathrm{mcg} / \mathrm{kg} / \mathrm{min})$ or not $(\mathrm{mcg} / \mathrm{min})$ and both methods are used in practice and clinical trials [16]. In a study by Radosevich and colleagues, obese patients with septic shock required less weight-based doses of norepinephrine and similar total doses compared to nonobese patients with no decrease in mortality [42]. Interestingly, Arabi et al. found that underweight and very obese patients with septic shock had fewer hemodynamic disturbances compared to normal weight patients with similar APACHE II scores and required lower amounts of norepinephrine and epinephrine [17].

SSC guidelines recommend the early administration of antibiotics [38]. However, the volume of distribution for many commonly used antibiotics can be altered in obese patients including vancomycin, macrolides, fluoroquinolones, and most beta-lactams leading to underdosing of these antibiotics in this patient population [43]. Studies have shown obese patients received a lower weight-based dose of antibiotics which may have confounded results [17].

Another limitation is the definition of obesity. The World Health Organization defines BMI using height and weight but this method has many limitations. Namely, BMI does not measure the percentage of body fat to body size, the type of fat, or the location of the body fat and overestimates the amount of fat for those with increased body density (e.g. increased lean muscle weight, high bone density) [44]. Abdominal obesity, one of the markers of metabolic syndrome, has been shown in population-based studies to be an independent and stronger predictor of mortality compared to BMI, especially for non-obese patients $[25,45,46]$. This finding is consistent even after correcting for BMI $[25,45]$. As well, inaccuracies with measuring height and weight may have led to erroneous BMI categorization. Aggressive fluid resuscitation in the emergency room can lead to increased BMI measurements. However, despite BMI classifications of body weight having many 
limitations, other methods of measuring fat such as waist circumference or computed tomography are not routinely performed or often feasible in the Emergency Department or ICU [3].

Additionally, previous studies did not describe the types of nutrition patients received, which may have confounded results. Sepsis may be a catabolic condition and malnutrition upon ICU admission may have attenuated the survival benefit in obese patients [47]. Studies have shown an association with decreased mortality in critically ill patients with enteral tube feedings high in protein $[47,48]$. As well, enteral tube feeding with excessive amounts of calories was associated with worsened morbidity, especially in obese patients [49]. In a large, retrospective cohort study, Harris and colleagues evaluated critically ill patients on enteral nutrition [28]. The study found that, in the early enteral nutrition subgroup, there were no significant differences in the adjusted hospital mortality between normal weight and overweight or obese patients [38]. As well, underweight patients had decreased to no reduced mortality compared to normal weight patients [28].

Another possible theory is that studies, which adjusted for co-morbid illnesses that are associated with increased BMI, may have decreased or negated the potential detrimental effects of obesity [3].

\section{Conclusions}

Studies have found a paradoxical benefit with obesity in regard to mortality with sepsis. The relationship between BMI and mortality with sepsis may be U-shaped with worsened outcomes for underweight and morbidly obese BMIs. However, results are controversial, data is limited, and results may be due to differences in patient characteristics. BMI is not a good indicator of quantity or quality of fat. Most of those with obese BMIs have increased incidence of metabolic syndrome with is associated with increased overall morbidity and mortality. Despite a possible benefit in mortality, morbidity, including length of stay in the ICU and length of intubation, is increased in obese patients. Large, prospective studies, which use consistent measurements of BMI, adjust for baseline characteristics, and utilize similar sepsis interventions, are required to interpret the possible protective effect of obesity in sepsis. Future prospective studies are suggested to address this important clinical issue.

\section{Additional Information}

\section{Disclosures}

Conflicts of interest: In compliance with the ICMJE uniform disclosure form, all authors declare the following: Payment/services info: All authors have declared that no financial support was received from any organization for the submitted work. Financial relationships: All authors have declared that they have no financial relationships at present or within the previous three years with any organizations that might have an interest in the submitted work. Other relationships: All authors have declared that there are no other relationships or activities that could appear to have influenced the submitted work.

\section{References}

1. Ogden CL, Carroll MD, Kit BK, Flegal KM: Prevalence of childhood and adult obesity in the United States, 2011-2012. JAMA. 2014, 311:806-814. 10.1001/jama.2014.732

2. Young T, Mei F, Liu J, Bast RC, Jr., Kurosky A, Cheng X: Proteomics analysis of H-RAS-mediated oncogenic transformation in a genetically defined human ovarian cancer model. Oncogene. 2005, 24:6174-6184.

3. Pepper DJ, Sun J, Welsh J, Cui X, Suffredini AF, Eichacker PQ: Increased body mass index and adjusted mortality in ICU patients with sepsis or septic shock: a systematic review and meta-analysis. Crit Care. 2016, 20:181. 10.1186/s13054-016-1360-z

4. Murphy SL, Xu J, Kochanek KD: Deaths: final data for 2010. Natl Vital Stat Rep. 2013, 61:1-117.

5. Angus DC, Linde-Zwirble WT, Lidicker J, Clermont G, Carcillo J, Pinsky MR: Epidemiology of severe sepsis in the United States: analysis of incidence, outcome, and associated costs of care. Crit Care Med. 2001, 29:1303-1310.

6. Fleischmann C, Scherag A, Adhikari NK, et al.: Assessment of global incidence and mortality of hospitaltreated sepsis. Current estimates and limitations. Am J Respir Crit Care Med. 2016, 193:259-272. 10.1164/rccm.201504-07810C

7. Cohen J, Vincent JL, Adhikari NK, et al.: Sepsis: a roadmap for future research. Lancet Infect Dis. 2015, 15:581-614. 10.1016/S1473-3099(15)70112-X

8. Kwizera A, Dunser M, Nakibuuka J: National intensive care unit bed capacity and ICU patient characteristics in a low income country. BMC Res Notes. 2012, 5:475. 10.1186/1756-0500-5-475

9. Lagu T, Rothberg MB, Shieh MS, Pekow PS, Steingrub JS, Lindenauer PK: Hospitalizations, costs, and outcomes of severe sepsis in the United States 2003 to 2007. Crit Care Med. 2012, 40:754-761. 10.1097/CCM.0b013e318232db65

10. Young T, Andersen HC: Tests of an approximate scaling principle for dynamics of classical fluids . J Phys Chem B. 2005, 109:2985-2994. 10.1021/jp0454927

11. Maley N, Gebremariam A, Odetola F, Singer K: Influence of obesity diagnosis with organ dysfunction, mortality, and resource use among children hospitalized with infection in the United States. J Intensive Care Med. 2017, 32:339-345. 10.1177/0885066616631325

12. Fleischmann E, Teal N, Dudley J, May W, Bower JD, Salahudeen AK: Influence of excess weight on mortality and hospital stay in 1346 hemodialysis patients. Kidney Int. 1999, 55:1560-1567.

13. Ng P, Eikermann M: The obesity conundrum in sepsis. BMC Anesthesiol. 2017, 17:147. 10.1186/s12871-017- 
0434-z

14. Rios-Diaz AJ, Lin E, Williams K, et al.: The obesity paradox in patients with severe soft tissue infections . Am J Surg. 2017, 214:385-389. 10.1016/j.amjsurg.2016.05.006

15. Lavie CJ, Milani R, Mehra MR, Ventura HO, Messerli FH: Obesity, weight reduction and survival in heart failure. J Am Coll Cardiol. 2002, 39:1563-1564. 10.1016/s0735-1097(02)01806-5

16. Prescott H, Chang V, O'Brien J, Langa K, Iwashyna T: Obesity and 1-year outcomes in older Americans with severe sepsis. Crit Care Med. 2014, 42:1766-1774. 10.1097/CCM.0000000000000336

17. Arabi YM, Dara SI, Tamim HM, et al.: Clinical characteristics, sepsis interventions and outcomes in the obese patients with septic shock: an international multicenter cohort study. Crit Care. 2013, 17:72. 10.1186/cc12680

18. Gaulton TG, Weiner MG, Morales KH, Gaieski DF, Mehta J, Lautenbach E: The effect of obesity on clinical outcomes in presumed sepsis: a retrospective cohort study. Intern Emerg Med. 2014, 9:213-221. 10.1007/s11739-013-1002-2

19. Kuperman EF, Showalter JW, Lehman EB, Leib AE, Kraschnewski JL: The impact of obesity on sepsis mortality: a retrospective review. BMC Infect Dis. 2013, 13:377. 10.1186/1471-2334-13-377

20. Wacharasint P, Boyd JH, Russell JA, Walley KR: One size does not fit all in severe infection: obesity alters outcome, susceptibility, treatment, and inflammatory response. Crit Care. 2013, 17:122. 10.1186/cc12794

21. Wurzinger B, Dunser MW, Wohlmuth C, et al.: The association between body-mass index and patient outcome in septic shock: a retrospective cohort study. Wien Klin Wochenschr. 2010, 122:31-36. 10.1007/s00508-009-1241-4

22. Yousef AA, Amr YM, Suliman GA: The diagnostic value of serum leptin monitoring and its correlation with tumor necrosis factor-alpha in critically ill patients: a prospective observational study. Crit Care. 2010, 14:33. 10.1186/cc8911

23. Pepper D, Demirkale C, Sun J, et.al.: Does obesity protect against death in sepsis? A retrospective cohort study of 55,038 adult patients. Crit Care Med. 2019, 47:643-650. 10.1097/CCM.0000000000003692

24. Akinnusi ME, Pineda LA, El Solh AA: Effect of obesity on intensive care morbidity and mortality: a metaanalysis. Crit Care Med. 2008, 36:151-158.

25. Martino JL, Stapleton RD, Wang M, et al.: Extreme obesity and outcomes in critically ill patients . Chest. 2011, 140:1198-1206. 10.1378/chest.10-3023

26. Robinson MK, Mogensen KM, Casey JD, et al.: The relationship among obesity, nutritional status, and mortality in the critically ill. Crit Care Med. 2015, 43:87-100. 10.1097/CCM.0000000000000602

27. Marik P, Bellomo R: A rational approach to fluid therapy in sepsis . Br J Anaesth. 2016, 116:339-349. 10.1093/bja/aev349

28. Harris K, Zhou J, Liu X, Hassan E, Badawi O: The obesity paradox is not observed in critically ill patients on early enteral nutrition. Crit Care Med. 2017, 45:828-834. 10.1097/CCM.0000000000002326

29. Flegal KM, Carroll MD, Ogden CL, Johnson CL: Prevalence and trends in obesity among US adults, 19992000. JAMA. 2002, 288:1723-1727.

30. Eckel RH, Grundy SM, Zimmet PZ: The metabolic syndrome. Lancet. 2005, 365:1415-1428.

31. Ruderman NB, Schneider SH, Berchtold P: The "metabolically-obese," normal-weight individual. Am J Clin Nutr. 1981, 34:1617-1621.

32. Wildman RP, Muntner P, Reynolds K, et al.: The obese without cardiometabolic risk factor clustering and the normal weight with cardiometabolic risk factor clustering: prevalence and correlates of 2 phenotypes among the US population (NHANES 1999-2004). Arch Intern Med. 2008, 168:1617-1624. 10.1001/archinte.168.15.1617

33. Stapleton RD, Dixon AE, Parsons PE, Ware LB, Suratt BT: The association between BMI and plasma cytokine levels in patients with acute lung injury. Chest. 2010, 138:568-577. 10.1378/chest.10-0014

34. Kolyva AS, Zolota V, Mpatsoulis D, et al.: The role of obesity in the immune response during sepsis . Nutr Diabetes. 2014, 4:137. 10.1038/nutd.2014.34

35. Arita Y, Kihara S, Ouchi N, et al.: Paradoxical decrease of an adipose-specific protein, adiponectin, in obesity. Biochem Biophys Res Commun. 1999, 257:79-83.

36. Bornstein SR, Licinio J, Tauchnitz R, et al.: Plasma leptin levels are increased in survivors of acute sepsis associated loss of diurnal rhythm, in cortisol and leptin secretion. J Clin Endocrinol Metab. 1998, 83:280283.

37. Borloz MP, Hamden KE: Sepsis in special populations. Emerg Med Clin North Am. 2017, 35:139-158.

38. Rhodes A, Evans LE, Alhazzani W, et al.: Surviving sepsis campaign: International Guidelines for Management of Sepsis and Septic Shock: 2016. Intensive Care Med. 2017, 43:304-377. 10.1007/s00134-0174683-6

39. Wiedemann HP, Wheeler AP, Bernard GR, et al.: Comparison of two fluid-management strategies in acute lung injury. N Engl J Med. 2006, 354:2564-2575.

40. Boyd JH, Forbes J, Nakada TA, Walley KR, Russell JA: Fluid resuscitation in septic shock: a positive fluid balance and elevated central venous pressure are associated with increased mortality. Crit Care Med. 2011, 39:259-265. 10.1097/CCM.0b013e3181feeb15

41. Piper AJ, Grunstein RR: Obesity hypoventilation syndrome: mechanisms and management. Am J Respir Crit Care Med. 2011, 183:292-298. 10.1164/rccm.201008-1280CI

42. Radosevich JJ, Patanwala AE, Erstad BL: Norepinephrine dosing in obese and nonobese patients with septic shock. Am J Crit Care. 2016, 25:27-32. 10.4037/ajcc2016667

43. Falagas ME, Karageorgopoulos DE: Adjustment of dosing of antimicrobial agents for bodyweight in adults . Lancet. 2010, 375:248-251. 10.1016/S0140-6736(09)60743-1

44. Schmidt DS, Salahudeen AK: Obesity-survival paradox-still a controversy? . Semin Dial. 2007, 20:486-492.

45. Pischon T, Boeing H, Hoffmann K, et al.: General and abdominal adiposity and risk of death in Europe . N Engl J Med. 2008, 359:2105-2120. 10.1056/NEJMoa0801891

46. Zhang X, Shu XO, Yang G, et al.: Abdominal adiposity and mortality in Chinese women . Arch Intern Med. 2007, 167:886-892. 10.1001/archinte.167.9.886

47. Weijs PJ, Stapel SN, de Groot SD, et al.: Optimal protein and energy nutrition decreases mortality in 


\section{Cureus}

mechanically ventilated, critically ill patients: a prospective observational cohort study. J Parenter Enteral Nutr. 2012, 36:60-68. 10.1177/0148607111415109

48. Allingstrup MJ, Esmailzadeh N, Wilkens Knudsen A, et al.: Provision of protein and energy in relation to measured requirements in intensive care patients. Clin Nutr. 2012, 31:462-468. 10.1016/j.clnu.2011.12.006

49. Dickerson RN, Boschert KJ, Kudsk KA, Brown RO: Hypocaloric enteral tube feeding in critically ill obese patients. Nutrition. 2002, 18:241-246. 